\title{
RELIGIÃO E METÁFORA SOCIAL: A SEMana Santa como Memória E ENCENAÇÃO DA HIERARQUIA EM MARIANA- MG
}

\author{
Paulo Gracino Júnior ${ }^{1}$
}

\begin{abstract}
Resumo
Neste trabalho, recupero a perspectiva de análise durkheimiana, que vê o fenômeno religioso tanto como uma projeção das relações sociais quanto uma fonte normativa para a sociedade. Mais especificamente, pretendo descrever, através da etnografia da Sexta-Feira Santa, a forma como a hierarquia e as disputas por poder vividas pela cidade mineira de Mariana são projetadas em sua vida religiosa. Para esse intento, baseei-me em um leque amplo de pesquisa, que contou com trabalho de campo, documental e entrevistas, através dos quais observei de que forma, a partir de um intenso processo de urbanização ocorrido dentre as décadas de 1970-1980, a cidade viu seu cenário marcado por uma contundente polarização sócio-espacial, envolvendo a população já estabelecida e o contingente recémchegado. Em meu entendimento, essa polarização incidiu de forma crucial na vida religiosa da cidade, sendo a religião não só uma projeção desse contexto, mas lugar privilegiado onde se encenam e re-atualizam as disputas de poder e dilemas dessa sociedade.
\end{abstract}

Palavras-chave: Cidade. Fenômeno religioso. Hierarquia social.

\footnotetext{
${ }^{1}$ Doutorando em Sociologia pelo Programa de Pós-Graduação em Ciências Sociais da Universidade do Estado do Rio de Janeiro (PPCIS/UERJ). End. eletrônico: paulogracino@hotmail.com
} 


\section{RELIGION AND SOCIAL METAPHOR: HOLLY WEEK AS A MEMORY AND MISE EN SCENE OF HIERARCHY IN A CITY OF MARIANA-MG}

\section{Abstract}

In this work, we draw on Durkheim's analytical perspective, which views religious phenomena both as a projection of social relations and as a source of norms for society. More specifically, we describe, through an ethnography of Holy Week, how the hierarchy and power struggles of the city of Mariana in Minas Gerais are projected onto the city's religious life. For this purpose, we based our work on a wide range of sources, including fieldwork, documents and interviews. Through these sources we observed how, as a result of an intense process of urbanization that occurred during the 1970s and 1980s, the city experienced a striking socio-spatial polarization, involving, on the one hand, the population already established and, on the other, the newly arrived contingent. In our view, this polarization powerfully impacted the religious life of the city, with religion serving not only as a projection of that context, but as a privileged space for the acting out and updating of the power struggles and dilemmas of society.

Keywords: City. Religious phenomenon. Social hierarchy.

\section{INTRODUÇÃO}

$1 \begin{aligned} & \text { este trabalho, recupero a perspectiva de análise durkheimiana, que vê o } \\ & \text { fenômeno religioso tanto como uma projeção das relações sociais quanto } \\ & \text { uma fonte normativa para a sociedade. Mais especificamente, pretendo }\end{aligned}$ descrever, através da etnografia da Sexta-Feira Santa, a forma como a hierarquia e as disputas por poder vividas pela cidade mineira de Mariana são projetadas em sua vida religiosa.

Para esse intento, baseei-me em um leque amplo de pesquisa, que contou com trabalho de campo, documental e entrevistas, através dos quais observei de que forma, a partir de um intenso processo de urbanização ocorrido dentre as décadas de 1970-1980, a cidade viu seu cenário marcado por uma contundente polarização sócio-espacial, envolvendo a população já estabelecida e o contingente recém-chegado. Em meu entendimento, essa polarização incidiu de forma crucial na vida religiosa da cidade, sendo a religião não só uma projeção desse contexto, mas lugar privilegiado onde se encenam e re-atualizam as disputas de poder e dilemas dessa sociedade. 
Antes de prosseguir, faz-se imperativo um adendo sobre o percurso teórico proposto, uma vez que as abordagens do fenômeno religioso que privilegiaram suas características funcionais/normativas - como são apresentadas em As formas elementares da vida religiosa (DURKHEIM, [1912] 2003) - foram alvo de críticas severas, em sua maioria dirigidas ao fato das análises "reificarem" o papel das estruturas e relegarem um espaço ínfimo ou nulo à agência². Como bem observa Steven Lukes (1984), nessa crítica, Durkheim seria visto como um determinista estreito que tomaria 0 ator social como simples marionete das formas estruturais do todo social. Obras de inspiração durkheimiana, como as de Halbwachs (1990 e 1994), Parsons (1974) ou Bellah (1984) receberam críticas similares.

Não obstante, um olhar retrospectivo sobre os principais trabalhos que se debruçaram sobre ofenômeno religioso nos últimos anos mostra que essepanorama vem mudando de forma significativa. Motivados pelo vendaval epistemológico das últimas décadas - que muitos classificariam de pós-modernidade (LYOTARD, 1989) - e pelo crescimento dos "novos movimentos religiosos" e do islamismo, vários autores têm acorrido às velhas teses durkheimianas, agora rejuvenescidas por um novo "movimento teórico" (ALEXANDER, 1987) ou pela mitigação de seus pressupostos estruturais (HERVIEU-LÉGER, 1993, 1997 e 2005a). São profusos os trabalhos de pesquisadores europeus que evocam os aspectos funcionais/ normativos da religião, como os italianos Roberto Cipriani (1993) e Enzo Pace (2006), a francesa Danièle Hervieu-Léger (2005b), o escocês Steve Bruce (2000) e a portuguesa Helena Vilaça (2008), que chamam a atenção para o enlace entre religião e identidade em estudos sobre os países europeus.

Nesse sentido, Hervieu-Léger (2005b) analisa as viagens do Papa João Paulo II como estratégias da cúria romana no intuito de mobilizar uma memória católica européia, fazendo coincidir passado europeu com passado cristão, no que a autora chama de "utopização' da Europa cristã do passado". Já Pace (2006) mostra-nos como mesmo os italianos, com fraca pertença religiosa, tomam 0 catolicismo como referencial da identidade nacional italiana quando em contraste com migrantes, como os mulçumanos.

Embora tratando de países de tradição protestante ou católica ortodoxa, como os países escandinavos e bálticos, Bruce (2000) mostra como, mesmo estando distantes das atividades institucionais religiosas, os dinamarqueses, por exemplo, atribuem valor positivo à manutenção da igreja Luterana Nacional por

\footnotetext{
${ }^{2}$ Lembramos aqui as críticas sobre a concepção etnocêntrica do sagrado na obra de Durkheim, tributada por seus críticos à sua origem judaica. A esse respeito ver Martelli (1995, p.63-74).
} 
parte do Estado. Inquérito realizado nesse país revelou que essa valorização advém da crença de que a Igreja Luterana é fiel depositária de boa parcela do patrimônio histórico nacional. Nesse sentido, Bruce observa que parte da população, mesmo pertencendo a alguma variante do luteranismo, realiza suas cerimônias cívicoreligiosas na igreja Luterana oficial. Citando o exemplo da Lituânia, Bruce mostra como a Igreja Católica foi fundamental no apoio ao sentimento de identidade nacional: no século XIX, frente à tentativa da Rússia czarista de padronização da língua; e no século XX, nos movimentos contra a "russificação" do país.

0 estudo de Vilaça (2008) nos mostra como a Igreja Ortodoxa desempenha um papel importante na integração dos imigrantes do leste europeu à sociedade portuguesa. Nesse estudo, a autora recorre claramente aos pressupostos da teoria durkheimiana ou aos dela derivados, numa mostra de que tais postulados ainda guardam um poder explicativo bastante profícuo nos dias atuais.

Cabe frisar ainda que neste trabalho, como nos trabalhos citados acima, os pressupostos durkheimianos são utilizados de forma indireta, mitigada, como pano de fundo analítico ao qual se somam contribuições de outros autores, como Norbert Elias. Sendo assim, o artigo foi subdividido em duas partes: a primeira descreve a formação histórico-estrutural dos grupos sociais dentro da cidade de Mariana, bem como as estruturas de poder estabelecidas e sua intrínseca relação com o processo de industrialização e urbanização da cidade; já na segunda, é analisada a projeção dessas estruturas sobre o campo religioso. Neste sentido, a religião será entendida não só como dispositivo assegurador do status quo citadino, mas como espaço privilegiado onde se encenam as disputas pelo poder e hierarquia.

\section{Os Marianenses e OS OUTROS: O PROGRESSO E A CHEGADA DOS “ESTRANHOS”}

Então foi uma vida que quebrou, não que eu sou saudosista - eu sou. Pode falar que eu sou! Porque quebrou aquela barmonia que tinba na cidade (...) (Excerto da entrevista de Rosa, diretora da ONG Amar Mariana) ${ }^{3}$

Cidade situada no norte da Zona da Mata Mineira, Mariana vai ter sua história marcada por dois elementos fundamentais: as jazidas minerais e a sua religião, elementos que parecem fundir-se e confundir-se na memória social local.

\footnotetext{
${ }^{3}$ Cabe ressaltar que muitas considerações apresentadas neste trabalho são fruto de um longo convívio na cidade de Mariana: primeiro como aluno do curso de graduação em História da
} 
Na narrativa da fundação da cidade, em 1696, história e memória se conformam para a criação de um "mito fundador", que ecoa ainda hoje nas mentes dos cidadãos marianenses.

Era 1696. E naquele dia crepitava em Mariana a chama de brasilidade que ardia no peito dos intrépidos bandeirantes do desbravamento, transformandose, em termos de trabalho, no primeiro acampamento — verdadeiro embrião de sociedade ativa e operosa - às margens do curso d' água que deram o nome de Ribeirão do Carmo, extensivo a localidade, com o intuito de explorar as potencialidades de apreciáveis reservas auríferas.

0 gênio bandeirante de Salvador Fernandes Furtado, chefe da expedição, não demorou — 0 depoimento é da História — na determinação de erigir, dia seguinte, o padrão de conquista em torno do qual o Capelão Padre Francisco Gonçalves Lopes rezou a primeira missa. Estava fundado o arraial, predecessor dos Bispados, a que sucederam a primeira Vila, a primeira cidade e, posteriormente a primeira capital de Minas, centro irradiador de ação civilizadora. (CAMÊLLO, 1991, p. 9)

Apesar dos elementos singulares exaltados pela identidade marianense, a cidade teve uma história bastante comum a dos outros centros urbanos coloniais de Minas Gerais. Quase todos viveram tempos de opulência no auge da idade aurífera, no século XVIII, bem como os tempos sombrios de sua decadência nos século XIX. Mariana não foi diferente; marcada, no século XVIII, pela febre do ouro que financiou as ricas construções barrocas, entra em declínio no século XIX, quando assiste à evasão de boa parte de seu contingente populacional para

Universidade Federal de Ouro Preto, de 1997 a 2000, depois como professor da cadeira de Sociologia da mesma instituição entre os anos de 2002 e 2004. Porém, as entrevistas foram recolhidas entre os anos de 2002 e 2007, durante as pesquisas para os trabalhos de mestrado e doutorado. Se, por um lado, o convívio na cidade e as relações pessoais já estabelecidas facilitaram o mapeamento e o contato com os entrevistados, por outro, ocasionaram alguns embaraços e omissões importantes nos depoimentos. Ainda que vários entrevistados tivessem cedido formalmente seu depoimento para a pesquisa, através de uma carta de cessão, optei por utilizar codinomes, para evitar constrangimentos comuns em uma cidade de relações sociais tão intensas como Mariana. Recorri a entrevistas temáticas, com questões pré-estabelecidas. Esse procedimento permitiu que a narrativa se ativesse à temática central, e os detalhes da vida pessoal do entrevistado fossem considerados à medida que se vinculavam ao assunto proposto pelo pesquisador. Foi utilizada a técnica do gravador, possibilitando captar adequadamente o discurso do informante e/ou seu diálogo com o pesquisador. Essa metodologia - comumente chamada pelos cientistas sociais e historiadores de "história oral" - indica que as falas dos informantes devem ser transcritas de forma literal, o que, no caso de minha pesquisa, revelou-se como mais um ganho, uma vez que permitiu uma maior aproximação do texto às falas reais dos informantes. 
o interior da Capitania, o que explica, em parte, a preservação de seu patrimônio (ALMEIDA, 1995).

No entanto, na década de 1960, um novo "ciclo" mineral trouxe à cidade outra leva de migrantes. Porém, dessa vez, não foi o ouro, mas as jazidas de minério de ferro, que atraíram três grandes companhias e seus operários. Uma vez mais, Mariana se viu revolvida por novos contingentes humanos. A chegada das primeiras mineradoras na cidade causou um processo de urbanização jamais sonhado nas melancólicas décadas anteriores. A sede do município, que nos anos de 1960 contava com menos de sete mil habitantes, terminou o século com mais de quarenta e cinco mil (IBGE 2007)4.

Em 1965, chegou a S. A. Mineração Trindade (Samitri), que, mesmo antes de sua ativação, já atraía um significativo contingente populacional, causando modificações no ritmo calmo da cidade (FISCHER, 1993). No entanto, o crescimento populacional da década foi bastante tímido: nesse período, a população da sede do município passou de 6.837 habitantes em 1960, para 7.720 habitantes em 1970 (FUNDAÇÃO JOÃO PINHEIRO [FJP], 1978).

Motivadas pelas reservas minerais e pelos gordos incentivos fiscais oferecidos pelo ímpeto desenvolvimentista ditatorial, aportaram em Mariana mais duas mineradoras: Samarco Mineradora S.A e a Companhia Vale do Rio Doce. A chegada na década de 70 (1977) da companhia Samarco provocou um fluxo de pessoas para o município bem mais significativo que o da década precedente. Segundo Fischer (1993), 10 mil pessoas se deslocaram para o município na época, muitas delas empregadas das empreiteiras, trabalhadores que, após as obras, permaneceram na cidade, mesmo desempregados. Na década de 1970, 0 crescimento demográfico foi bem mais significativo: a população da sede, que era de 7.720 habitantes, chegou ao final da década com 12.853, mostrando um crescimento de 18,63\%, índice superior ao do Estado no mesmo período (FJP, 1980). Em 1979, foi a vez da Companhia Vale do Rio Doce (CVRD) começar a construir suas instalações na cidade, para iniciar a produção em 1984.

As companhias mineradoras trouxeram consigo muito mais que operários e suas famílias: com elas vieram novas idéias, novas visões, novos problemas sociais, que logo contrastaram com o jeito de viver e as idéias da população estabelecida na cidade. 0 tão esperado desenvolvimento veio, mas não com shoppings e grandes magazines: ele trouxe a instabilidade, a fugacidade e a incerteza.

${ }^{4} \mathrm{http}: / /$ www.ibge.gov.br/cidadesat/topwindow.htm?1 
Se até a década de 1960 a chamada "cidade velha" abrigou quase toda a população da sede urbana, nas décadas posteriores, principalmente no período que vai de 1975 a 1985, há uma rápida transformação no espaço urbano da cidade. A chegada das mineradoras e seus operários demandou o planejamento e a construção de bairros (chamadas Vilas) exclusivos a esses, que dispusessem de serviços básicos dos quais o resto da cidade carecia, tais como escolas, serviço médico, clubes sociais, supermercados e serviço de água, entre outros.

Neste período, observa-se o incremento da ocupação da chamada "cidade nova" e o surgimento de vários bairros periféricos nas cercanias da cidade e nas regiões ribeirinhas ao Ribeirão do Carmo, chamadas "prainhas". Esses bairros, bastante insalubres, foram fruto de uma ocupação desordenada do espaço, levada a efeito durante a década de 1980 por políticas clientelísticas muito comuns na região. Em um trabalho anterior (GRACINO JÚNIOR, 2005), constatei que os dois bairros mais pobres do município, Cabanas e Santo Antonio (Prainha), tinham sua população formada em sua maioria por pessoas vindas da zona rural ou de outros municípios, 59 e 60\% respectivamente (IBGE, 1991). Nesses bairros, os índices de renda, violência e escolaridade também não são favoráveis.

Depois de passada a "febre do progresso", vivida nos primeiros anos de industrialização, os "estabelecidos" voltaram-se para um projeto higienista, que visava civilizar ou, se possível, extirpar esse excedente populacional indesejável à "harmonia barroca" da cidade. Foram várias as tentativas e projetos de remoção da população migrada e sem emprego do município.

Lembrando o que nos diz Bourdieu (1998), para quem a hierarquização dos espaços se torna cada vez mais proeminente no "contexto global", podemos imaginar que ela está na ordem do dia mesmo em cidade menores, como o caso de Mariana. Nesta, também vemos a tentativa de "revitalização" do centro histórico da cidade, bem aos moldes de outras cidades-patrimônio como Salvador, Olinda ou Porto, em Portugals.

0 "conjunto arquitetônico da cidade" é pensado como um lugar ideal, sem mendigos, vagabundos ou pobres. Se eles existem, é preciso encobri-los para que não apareçam, para que não atrapalhem o bom andamento da vida cotidiana: 0 comércio e o afluxo de turistas. Para lembrar Bauman:

Os turistas ficam ou se vão ao bel-prazer. Deixam o lugar quando novas oportunidades não experimentadas acenam em outra parte.

\footnotetext{
${ }^{5}$ A esse respeito ver Peixoto (2005).
} 
Os vagabundos sabem que não ficaram muito tempo num lugar, por mais que o desejem, pois provavelmente em nenhum lugar onde pousem serão bem recebidos.(...) Sinal verde para os turistas, sinal vermelho para os vagabundos (...) Não há turistas sem vagabundos e os turistas não podem ficar à solta se os vagabundos não forem presos. (BAUMAN, 1999, p 102).

É justamente "prender vagabundos" o mote da "população tradicional" da cidade e, por conseqüência, do poder público municipal. Porém, aqui, não são usadas grades ou correntes, mas o capital simbólico acumulado pelo grupo hegemônico (BOURDIEU, 1989).

Desta forma, a cidade de Mariana pode ser dividida em três grupos populacionais, utilizando como critérios o local de moradia, o tempo de estabelecimento na cidade, a ocupação e o auto-reconhecimento como pertencente ao grupo. Sem querer ser exaustivo e tendo em mente as implicações e limites de uma classificação como esta, tomo os referenciais de autoclassificação local mediados pelos da Teoria Social.

Tomando por base esse critério, posta- se, em um extremo, o grupo que se auto-reconhece como "moradores tradicionais" da cidade, composto por famílias locais e tradicionais, que ainda se mantêm em grande parte no antigo núcleo histórico. Estas famílias, mesmo não compondo um grupo numericamente majoritário, nem muito homogêneo, exercem a hegemonia político-socialreligiosa na cidade.

No intermédio, tem-se o grupo constituído pelas famílias dos trabalhadores das mineradoras, ou simplesmente "trabalhadores da Vale," que compõe um segmento de padrão econômico relativamente elevado. São famílias vindas de outras cidades de Minas Gerias, com hábitos e expectativas próprias. Essas famílias têm pouca ou nenhuma participação na vida político-social da cidade. Além de residirem em bairros distantes do centro histórico, têm seus próprios centros de lazer, construídos pelas mineradoras, seus supermercados e suas escolas. Somado a isso, pode-se destacar a consciência de sua transitoriedade: uma vez extintas as jazidas de ferro, irão para outro local. Esta consciência pode ser notada, entre outras coisas, pela baixa participação política nas eleições municipais, uma vez que a imensa maioria nem sequer vota no município (NEASPOC-UFOP, 2000) ${ }^{6}$.

No outro extremo, está o grupo constituído por segmentos populacionais vindos, em sua maioria, da zona rural, ou de pequenas cidades das cercanias do

${ }^{6}$ Núcleo de Estudos Aplicados e Sócio-políticos Comparados ligado à Universidade de Ouro Preto. 
próprio município, atraídos pela possibilidade de conseguir empregos ou pela esperança de obter um lote de terra. Este grupo apresenta um poder aquisitivo muito baixo e constitui, numericamente, o mais significativo da cidade.

É interessante notar que, mesmo estando segmentada em três grupos bem distintos, a sociedade marianense vai assistir a uma polarização contundente entre o grupo de moradores que se auto-reconhece e é reconhecido como "tradicional", e o último, migrado para a região em busca de emprego e moradia. Não obstante 0 abismo social que separa esses dois grupos, a renda não é o principal diferenciador, tornando-se secundária, ou mera demonstração de sobriedade, retidão, coesão familiar e trabalho dos moradores "tradicionais". Exemplo disso é que são consideradas "tradicionais" várias famílias residentes no centro histórico, porém em casas bastante modestas e renda familiar similar ao do grupo recém-chegado.

Por ter como baliza mais importante de autoclassificação o critério de antiguidade, proponho utilizar os referenciais expostos na obra de Elias \& Scotson (2000). Mutatis mutandis, vejo em Mariana, que o grupo mais antigo colocase como establishment e se autopercebe e é percebido como pertencente a uma "boa sociedade", mais poderosa e melhor, com uma identidade social construída através de tradição, autoridade e influência: fundando seu poder no fato de ser um modelo moral para os outros. Contrário aos estabelecidos, são os forasteiros, ou outsiders.

A "boa sociedade" se ancora a uma auto-imagem construída sobre uma possível ascendência nobre dos tempos coloniais e dos seus antepassados ricos fidalgos, em que Mariana era a grande cidade da Capitania das Minas Gerais. Enquanto isso, a população forasteira não passa de mera intrusa, composta por pessoas sem cultura, de hábitos rudes e pouco afeitas ao trabalho. Tal como seus antepassados, a missão dos estabelecidos - dos "cidadãos de bem" - é apartarlhes à cidade ou, quando muito, domesticar-lhes. No entanto, como veremos, a identidade não se faz sem uma boa dose de esquecimento, que além de um fazer social, é um ato violento de poder (POLLAK, 1989).

Após a rápida urbanização, a população "tradicional” logo cunhou termos para classificar a nova realidade social: "cidade nova", "cidade velha", "prainhas", "cabanas", "morador da cidade", "trabalhadores da Vale" e "gente de fora", são termos que se tornam hegemônicos na descrição espacial da cidade. Aqui, como nos lembra DaMatta (1985), não se trata de mera descrição geográfica: os termos têm conotações sociais locais, exprimem "regiões sociais" que revelam relações de poder, antiguidade e hierarquia entre os espaços. 
Não é difícil inferir o desenrolar desse processo. É claro que os ideais "progressistas" das famílias "bem nascidas" não podiam conviver com uma "malta" de pessoas que não compartilha minimamente seus anseios.

Todavia, num primeiro momento, o ideal de progresso suplantava qualquer outro sentimento e as contradições trazidas pela rápida urbanização ainda não eram sentidas pelos "cidadãos" de Mariana, ou, estes estavam dispostos a pagar o preço. Foi na década 1990 que a cidade começou a viver sua "crise de confiança" no progresso, pelo menos no representado pelas mineradoras. Como podemos ver no depoimento de Margarida, membro de uma $\mathrm{ONG}$ preservacionista do município:

Eu fico pensando, como que eu deixei acontecer isso tudo, parece que eu tive amnésia esse tempo todo, porque hoje eu trabalho demais, mas eu fujo do meu serviço e vou defender Mariana, a qualquer hora. E por que que eu fiquei quieta esse tempo todo. Parece que tava anestesiada, parece que eu congelei. Eu não tinha a consciência do que tava acontecendo. Hoje em dia eu vejo 0 arrependimento que eu tenho, como se diz, de não ter caído a ficha a um tempo atrás, do que Mariana precisava na época. Por que que eu não bati 0 pé, eu tenho um remorso de não ter acordado a um tempo atrás, com a visão que eu tô hoje.

Com a industrialização, a população cresceu, baixos níveis de escolarização e saneamento básico foram somados a altos índices de desemprego e delinqüência, como se denota do depoimento do senhor Arnaldo Gomes, pertencente à Ordem Terceira de São Francisco de Assis:

Com isso a cidade cresceu muito, que até 1970, como eu ia dizendo, Mariana era uma cidade pacata. Hoje não, é uma cidade que deve ter ai... mais de dois ou três mil veículos, só carros, trafegando ai pelas ruas da cidade. Não é?

Com isso a cidade cresceu muito. Também, em compensação, veio muita miséria, a pobreza que existe muito, roubos, crianças, pivetes roubando, as pessoas aí. A polícia toma providência, quando toma! Mas a justiça manda soltar porque é menor. Eu conheço um aqui que me assaltou, ele já foi umas dez vezes na cadeia, e tem ai Bispo, com Conselho Tutelar, com não sei mais o quê aí... tudo pra proteger os menores aí... e eles fazendo o diabo aí e ninguém toma providência, autoridade nenhuma toma providência. Nós tamo aqui em Mariana com uma cidade sem lei, principalmente nesse caso aí. Assalto à mão armada, roubos, etc. 
Nesse momento, a população abastada do município se pergunta: "o que teria acontecido com a sociedade marianense, até então baluarte da moral e dos bons costumes?", "Estaria corrompida?", "Mas de quem seria a culpa?".

Com a notoriedade das mazelas do progresso, a sociedade estabelecida cria uma auto-imagem exemplar, mais uma vez fundada em seu passado. 0 ideal de progresso é deixado um pouco de lado, agora associado à chegada do elemento "anômico", que desestabilizou a "ordem”. A preservação do casario, das igrejas, volta a ser importante, pois são espaços dominados pelos estabelecidos; são símbolos do passado e da história da cidade.

Os estabelecidos atribuem todos os problemas sociais da cidade aos forasteiros, que são vistos como pessoas menores, de má índole. Sem história, sem passado, sem nome de família, como parece ficar patente nesse outro trecho do depoimento de Margarida, em especial nos trechos em negrito:

(...) se as mineradoras não tivessem vindo para Mariana, Mariana tava muito mais [pausa] vivendo uma qualidade de vida melhor, sem problema nenhum, questão de social, porque não ía ter essa pobreza que tem aqui, porque essa pobreza veio junto com elas, com as companhias. Mariana não tinha essa pobreza que você vê nas ruas, as pessoas comiam bem. Elas plantavam, elas colhiam, tinham criação de galinha. Na nossa própria cidade mesmo nós tínhamos criação de galinha, horta nas casas. Então nós vivíamos com aquela vida saudável. Então o quê que acontece? Elas vieram pra cá [as companhias mineiradoras]. Se elas gerou emprego pros marianenses, elas tirou muito mais do que gerou. Ela injetou aqui, piãozada, que engravidou família, se lembra disso? [pergunta para a amiga] Essa Prainha mesmo começou com a Vale [pausa] aquela infelicidade! [Grifos nossos]

PESQ.: Pensei que a Prainha já existisse?

Não, a Prainha foi construída depois da Vale, aquilo ali na Prainha era um tipo assim, dormitório de pião, alojamento. Depois é que começou, tinha um forrozinho, tinha um butequinho. Por exemplo, o homem engravidou a mulher, fez, fez, já fazia um barraco ali mesmo. Por isso que eu falo: as mineradoras tirou muito mais de Mariana, do que ofereceu. A vida inteira!

No entanto, as pessoas vindas para a sede do município não estavam só em busca de um emprego, de uma casa. Estavam em busca de "dignidade" e queriam partilhar, a seu modo, da vivência da cidade. Como observa Lefebvre (1991, p. 104) 
Trata-se da necessidade de uma atividade criadora, de obra (e não apenas de produto e de bens materiais consumíveis), necessidade de informação, de simbolismo, de imaginário, de atividades lúdicas. Através dessas necessidades vive e sobrevive um desejo fundamental (...) que superam mais ou menos a divisão parcelar dos trabalhos.

Todavia, todos os espaços da cidade lhes são fechados, negam-lhes a cidade, alienando-os de seu espaço. Nessas guerras espaciais, para usar o termo de Bauman (1999), o grupo com maior coesão interna tende a lançar estacas mais firmes, contar com um aparato mais eficaz de constrangimento e poder. Em nosso caso, o grupo de moradores tradicionais da cidade, com uma coesão interna muito maior (não obstante as tensões), vale-se mais eficazmente do poder. Além de dominar o aparato institucional (jornais, cargos públicos), usa-o para reforçar seu poder, invariavelmente, apartando ou estigmatizando o estrangeiro.

A estigmatização mostra-se bastante eficaz, uma vez que os próprios indivíduos se sentem como que impuros para certos lugares. Cria-se uma espécie de "cordão sanitário" na cidade, que se materializa em várias ações e propostas que visam à preservação do bucolismo da cidade velha. 0 excerto da entrevista de Dona Eleonora, 75 anos, tradicional moradora do centro histórico:

Um político muito famoso aqui de Mariana, que foi secretário [Estadual] de cultura, filho aqui de Mariana, sugeriu um cinturão, aqui pra proteger 0 centro, o resto fazia o que quisesse, mas nunca foi aceito isso. (...)

Esta "alienação" do espaço da cidade é mútua. Da mesma forma em que há quase um imperativo categórico quanto ao trânsito de indivíduos da "periferia" em certos lugares da cidade, os "bem nascidos" sentem que certos espaços são indignos de sua presença. Estes até podem circular, aqueles não devem circular.

Um exemplo disso foi o resultado de uma pesquisa feita no ano 2000 por um núcleo de pesquisa ligado a Universidade Federal de Ouro Preto (NEASPOC), que tem seu centro de Ciências Humanas situado na cidade de Mariana. Ao serem perguntados sobre a importância do patrimônio histórico, mais de 85\% da população desconhecia o que significava tal expressão. Muitos jamais entraram em uma igreja barroca, ou em um museu. 0 depoimento do senhor João Mendes, migrante e morador da periferia da cidade, pinta o que dissemos em cores vivas:

Depois que vim de Pedras [Distrito de Mariana] pra morá aqui na cidade em... acho que 1986, pensava que ia tê uma vida meió, maise, nóis... No primeiro ano não consegui emprego, meus fio tava tudo duente, não tinha 
dinheiro nem prum pão. Ai o prefeito João Ramos - [pausa] oh home bão!deu esse terreninho que ocê tá vendo aí e nóis construiu nossa casinha (...) Maise na igreja lá du centro, da Sé, nóis nunca colocô o pé. Só minhas fia, que já foram num batizado lá, maise eu não, igreja de rico...Nóis não é bem vindo lá não(...) Fiquei muito tempo sem í à igreja despois que vim aqui pra Mariana, só fui voltá despois que entrei pra crente, lá sim é bom todo mundo é pobre ninguém ri da gente. Maise antes, nóis não saía daqui pra ir em missa de rico, lá na Sé, na São Francisco, só tem gente bem vestida. 0 quê que eu vô fazê lá, pra eles ri de nóis, eu não.

Como já argumentei, a segregação dos lugares da cidade não se dá apenas no meio da população forasteira, a população do centro desconhece bairros populares que ficam a menos de meio quilômetro do centro da cidade, como é o caso do bairro "Prainha", um dos mais pobres da cidade. Ir ao bairro é um verdadeiro tabu. Mariana como um todo apresenta a desigualdade de acessos aos seus equipamentos, espaços, lugares, determinando a alocação de seus cidadãos de acordo com seu local ocupado no quadro da cidadania (BAUMAN, 1999).

No entanto, pode-se dizer que existem alguns espaços comuns a esses dois grupos. Nesses espaços, forasteiros e tradicionais se (des)encontram. Nos fins de semana, por exemplo, em especial aos domingos, a população egressa da missa das seis da tarde segue em direção à praça. Após circular por algum tempo e encontrar os amigos, reúne-se nos bares que ficam no seu entorno. Neste momento, é impossível não perceber, mesmo para os olhos mais desavisados, a marcante divisão do espaço da praça. No lado de "cima" - que aqui não indica altura, pois a praça fica em terreno plano - dispõem-se pessoas predominantemente "brancas", enquanto na parte de "baixo" os rostos mestiços formam a ampla maioria. No lado de "cima" existem dois bares: um congrega a população adulta e, invariavelmente, toca MPB; o outro reúne jovens e adolescentes, quase sempre embalados por uma banda de rock cantando as últimas das paradas de sucesso. Já na parte de "baixo", que também conta com dois bares, o som predominante é 0 funk, entoado de cor e a plenos pulmões pelos que ali se aglomeram.

É um espetáculo intrigante ver que, mesmo sem nenhuma linha física que dividisse o espaço da praça, a mesma estava partida, sem que nenhum dos integrantes de cada um dos lados tentasse "invadir" o espaço do outro; 0 entendimento era tácito. $\mathrm{Na}$ cidade, mesmo os pontos de interseç̧ão entre estabelecidos e outsiders são verticalizados, sejam eles a igreja matriz, o jardim central, ou nos festejos da Semana Santa, que passo a narrar a seguir. 


\section{A Composição da Cena: dias EsPeciais}

Era dia 25 de março de 2005, anunciava-se como um dia típico na montanhosa cidade de Mariana. Meio nublada e chuvosa, aquela manhã começou lenta, como convém a um dia de feriado, porém a ausência dos sons dos sinos que dobravam - convocando os moradores para a missa das oito- deixa no ar um vazio. No entanto, com o avançar do dia e um sol meio tímido, as pessoas se agitavam, podendo-se escutar o burburinho da vizinhança, em que senhores e crianças se preparavam para a festa. São as comemorações da Semana Santa, estamos no ápice das rememorações - a Sexta-Feira Santa, em que se revive a paixão e morte de Cristo.

Desci para ver a encenação da Paixão e morte de Cristo (com atores da cidade), que seria seguida da "procissão do enterro". Naquela data, reuniam-se na cidade, além do turista e do marianense-ausente, outros tantos, vindos da zona rural ou dos bairros pobres do município, que não cabiam bem nas categorias acima. Aos olhos dos "marianenses", eram apenas outros, que deviam guardar bem o seu lugar, para não destoar da "cena" (JEUDY, 1995) montada para mostrar ao turista e reavivar ao marianense o quão católico é seu povo e sua cidade.

Estava hospedado em uma casa próxima ao centro-histórico, num bairro chamado São Gonçalo. Reeditando a classificação espacial local, seria um meiocaminho, uma transição entre o centro antigo e a periferia. Nos quinze minutos de caminhada que me separavam do centro-histórico e das comemorações, podia observar a mudança nos rostos e no cenário da cidade. À medida que descia, as casas se tornam menos "desordenadas", as ruas mais regulares, formando um conjunto bem mais agradável aos meus olhos acostumados e socializados, nas "ordenadas" cidades modernas. Muda a paisagem, mudam também as faces e os trajes dos transeuntes; as roupas improvisadas - bermudas-de-calça, camisas poídas e os semblantes turvos-mestiços, marcados pelo tempo, numa mistura de suor e poeira do minério de ferro, vão paulatinamente dando lugar aos rostos rubros, cabelos bem arrumados e trajes sóbrios da população tradicional da cidade. São as "filhas de Maria", os membros das veneráveis irmandades, as beatas, as senhoras e senhores de respeito da cidade, que tem lugar importante na festa que se enseja. 0 cenário antes turvo-amarelado vai tomando um tom brancoacinzentado, em que se misturam os trajes - requeridos pela ocasião - e a cor do casario. As fachadas acanhadas, modestas e encardidas, dão lugar aos amplos casarões, que se fazem (ou melhor, não se fazem) entrar por portas igualmente 
suntuosas, providos de sacadas bem trabalhadas em pedra-sabão, ou em metal, que guardam segredos impenetráveis aos olhos forasteiros.

Vou descendo e deixo para trás as pequenas imagens de santo, guardadas nos toscos quartos de dormir, geralmente ao lado de uma vela pela metade - símbolo de um pedido - e de um terço (desses de contas grandes, que têm na extremidade um crucifixo com a imagem do Jesus crucificado) pendurado na parede em forma de cruz. Agora, estou chegando ao centro-histórico e já avisto os "Passos" , pequenas ermidas construídas no século XIX, que, segundo a reminiscência local, têm quase trezentos anos - "Essa é dos tempos de D. Frei Manuel da Cruz !"8, aponta uma senhora com orgulho. Nessas ruas, nas quais, segundo a memória, passaram os varões mais ilustres ${ }^{9}$ da sociedade mineira, quiçá brasileira; onde se ergueram os pilares mais sólidos da mineiridade e, sobretudo, mantém-se sob duros percalços a fé católica, devem ser, e são, palcos legítimos das encenações e percurso sagrado da procissão que se anuncia no tilintar das matracas.

Meus olhos interessados, porém já socializados ao método especulativo moderno, fazem-me baconianamente duvidar daqueles ídolos e, provavelmente, não captar mais que uma fresta do sentido do simbolismo e da euforia que tomam o coração daquela gente. Cruzando a chamada Ponte de "Areia", que dá acesso à Rua Direita, observo seu contorno e o arco que desfecha sobre as águas do córrego do Catete. Admirando a magnífica obra, nada das bucólicas rimas dos poetas sobre o lugar me vem à mente, senão a posteriori - e, mesmo assim, cortadas pelo criticismo histórico que cruza de forma fulminante minha memória sobre os lugares (NORA, 1993).

Sigo a Rua Direita, preferindo tomar o caminho mais longo para chegar até a praça, hoje chamada Minas Gerais, ponto alto das cerimônias. Os transeuntes se adensavam e, ao menos naquele momento, se misturavam. Ainda que durasse pouco, era interessante ver figuras tão díspares andando ombro a ombro. É claro

\footnotetext{
${ }^{7}$ Passos são pequenas ermidas, construídas em sua maioria no século XIX, que situadas a lado das residências, nas beiras das ruas, contém em seu interior a imagem de Cristo, representando os Passos da Paixão. É interessante notar que as imagens possuíam cabelos humanos, muitas vezes eram representadas com chagas, que, juntamente com as vestes púrpuras, deram-me um aspecto assustador.

${ }^{8}$ Menção ao primeiro Bispo de Mariana, que tomou posse em 1748, permanecendo em seu pontificado até 1764 .

${ }^{9}$ Alusão ao título de uma das obras épicas sobre a história de Mariana que muito contribuíram para minha imersão no universo e nas memórias de parte da sociedade marianense, Mariana: Berço de Varões Ilustres (BOV0,1974).
} 
que, tão logo começassem as comemorações, cada qual tomaria seu lugar, social e simbólico, dentro dos festejos. Ao fim da Rua Direita, cruzo a Praça Cláudio Manoel, sob a sombra da catedral da Sé de Mariana, que se apresenta imponente, com suas torres e sinos; corto caminho pelo adro da igreja e encontro a Rua Frei Durão; mais alguns passos e estou na Praça Dr. Gomes Freire (proeminente político da cidade).

Nesse trajeto, fixado nos nomes das ruas e lugares, lembro de um trecho do livro comemorativo do dia de Minas Gerais (16 de julho, possível data da "invenção" da Vila do Carmo -Mariana), o excerto dizia o seguinte:

(...) Onde andam os genuínos mineiros de antiga cepa? Em que labirintos e corredores encontra-los? Em que biblioteca revê-los e repensa-los? As montanhas apontam o caminho a novos bandeirantes que se fazem necessários hoje, para que Minas seja redescoberta no seu dia. Onde andam os pés do Coronel Garcia? E Salvador Furtado de Mendonça? E as mão iluminadas de Atayde? E o cinzel barroco do Aleijadinho, Antonio Francisco Lisboa? Onde anda a cabeça do Alferes, coroada de liberdade em tempo de escárnio? Onde anda Gomes Freire de Andrade? Os Pinheiro Chagas? 0 recentíssimo e antigo menino Drummond e o seu irmãozinho Pedro Nava? E todos os Melo Franco de Andrade? E os Alphonsus? ${ }^{20}$

Mais uma vez, tomado pelo desencanto histórico, como Brecht, perguntome onde estão todas as Marias José? E os Josés Maria? Os Domingos? Onde estão as mulheres e homens que ajudaram a construir tanta história? Não têm história? Não há lugar para essas pessoas na cena gloriosa da barroca-cidade? Por que foram apagados os transeuntes que o inglês Richard Burton narrou com uma boa doze de humor e etnocentrismo? Pode-se pensar, como o fez Jeudy (1995), que a reconstituição da memória ou da imagem de um bairro - neste caso, de uma cidade - conjuga-se com uma "limpeza" da população heterogênea, uma espécie de regeneração da vida social. Senão, como explicar que sejam ocultados em quase todos os relatos sobre Mariana, a população "mestiça", os bêbados e os vagabundos, em prol dos grandes nomes? Esta "contradição" só aflora nos relatos mais argutos dos estrangeiros:

Estávamos, evidentemente, em uma cidade clerical e não comercial: a apatia era a que reina, geralmente, nas cidades catedrais, de Itu, em São Paulo, a Durham e Cantuária, antes da idade das estradas de ferro. Formigões, como os seminaristas, com as sotainas negras, são chamados galhofeiramente, caminham

${ }^{10}$ Discurso proferido por Geraldo Reis, Um dia de Minas Pelo Resgate da Mineiridade. (CAMÊLLO, 1991) 
pelos logradouros e ficam parados, indolentes, perto das lojas. 0 negociante debruça-se, com cotovelo no balcão, e olha vagamente a rua, ou medita e fuma, juntamente com um amigo ou amigos, sentados em tamboretes, mais perto da porta. Os negrinhos andam pelas ruas ou provocam porcos e cães vadios, que, segundo parece, constituem a maior parte da população; uma das criaturas, que certamente não ouvira falar em Joana d'Arc gritou, "Deus me livre!", quando passamos por ela. Pretas velhas erravam, arrastando mutambos, e notamos vários homens brancos descalços, espetáculo muito raro no Brasil. Aqui e ali, uma profusão de cabelos lisos, lustrosos e bem engordurados, com uma vistosa flor vermelha do lado esquerdo da cabeça, e um rosto de sangue muito misturado, empenhados em um "sério estudo das cenas da rua", informavam aos olhos práticos que, como era de se esperar em uma terra onde os moços "estão destinados à Igreja" o Anônimo é tão conhecido como os que "vivem em Gondar". ${ }^{11}$

Enfim, chego à Praça Minas Gerias, o que mais me chama a atenção são os tons de roxo, bem como a disposição das pessoas. A praça formava um cenário perfeito: de um lado, o palco, montado no adro da igreja pertencente à Venerável Ordem Terceira de São Francisco de Assis, tendo à sua frente a Casa da Câmara Municipal e, à sua esquerda, a igreja pertencente à Confraria de Nossa Senhora do Carmo. No centro da praça, meio esquecido, embora em lugar de destaque, um pelourinho, tendo no alto o globo e a coroa, a espada e a balança, bem como os buracos por onde os criminosos eram amarrados. Talvez esse fosse o único símbolo que destoasse da cena, aparecendo, aos meus olhos, como um prenúncio de que 0 tempo passado não era feito só "de chuva e negócios bons”, como diria Guimarães Rosa.

A praça estava quase toda tomada, pessoas das mais variadas estirpes se acotovelavam em busca de um lugar para assistirem às cerimônias, embora, em uma visão mais de perto, fosse possível observar nitidamente as fronteiras que separavam as parcelas da população.

Ainda que a cidade de Mariana se apresente como uma sociedade bastante secularizada, nos termos que propõe Weber, o comparecimento em eventos comunitários ligados à religião ocupa um lugar central dentre as atividades de lazer de um bom número de famílias locais. Pode-se dizer que as festas religiosas, bem como algumas outras atitudes sociais, consistem-se num bom exemplo de articulação entre posturas tradicionais e modernas, aos moldes da que propõe Canclini (1998, 2001 e 2003).

${ }^{11}$ Relato do inglês Richard Burton, que esteve na cidade em 1867 (BURTON, 1975, p. 272-3). 
Desta forma, as festas, de modo geral, e a Semana Santa, em especial, apresentam-se como um lugar importante, seja para o grupo tradicional, que faz da ocasião um momento de demonstrar seu prestígio, seja para o forasteiro, que tem a oportunidade de se colocar ombro-a-ombro com a "boa sociedade". Dito de outra forma, o grupo tradicional faz da ocasião a oportunidade para mostrar aos seus e aos outros o quanto são importantes, seja pelo lugar de destaque ocupado nas cerimônias ou pelas roupas que, aquele ano, estavam mais bem cortadas e alinhadas que as da família X ou Y. Para as famílias pobres dos arrabaldes do município, além de uma excelente oportunidade de socialização com os de seu grupo - uma vez que dali saíam namoros, casamentos e negócios - tratava-se de uma boa ocasião para observar o comportamento da "gente rica da cidade", o que poderia servir tanto como padrão de comportamento quanto de tema para os comentários galhofeiros do dia seguinte - sobre o corte do vestido de uma ou outra senhora, o tropeção do senhor fulano ao carregar o andor de um santo.

$\mathrm{Na}$ faixa de espaço ocupada pela população tradicional, muito mais homogênea em sua composição, seja pelo vestuário, que parece se uniformizar - embora a intenção seja se diferenciar - seja pela cor da pele, ou pelos cabelos bem arrumados, reinam olhares taciturnos, gestos pensados e comedidos de quem conhece tacitamente todos os códigos pertinentes àquele espaço. Já na faixa ocupada pelos forasteiros, visivelmente pouco coesa, formada por pessoas dos extremos opostos do município, vê-se as mães que, sozinhas, tentam apartar o choro das crianças, ou jovenzinhas que cochicham sob os olhares vigilantes e reprovadores de um ou outro morador tradicional, que, por ter chegado um pouco atrasado, teve que se contentar, "desterritorializado", com um lugar ali mesmo.

A encenação vai se desenrolando, em meio a cochichos, choros das crianças e até alguns flertes, quando, voltando sua atenção para a cena, um senhor da platéia comenta:

— "É, nosso povo tá muito sofrido, Jesus tinha que vir de novo pra nos salvar!" — ao que, logo, é retrucado por outro:

— "Se Jesus voltasse, eles matavam ele de novo. Atualmente, só temos Judas!" — é o momento do suicídio de Judas.

Passo os olhos pela platéia e vejo quase que um êxtase, alguns ficam nas pontas dos pés para ver, outros apertam suas próprias mãos, seguidos de tímidas manifestações:

— "Bem feito!" 
— "Traidor!".

No entanto, logo após o desfecho desse ato, a platéia é tomada por um silêncio absoluto, cortado, momentos depois, pela voz do ator que interpreta Jesus:

— "Deus meu, Deus meu, por que me desamparaste?" — era a encenação da morte de Jesus.

A platéia, indistintamente, foi tomada por uma emoção contagiante. Senhoras com seus filhos no colo abraçavam a criança, como se quisessem se consolar; um senhor, que estava à minha frente, murmurou um "não"; outras senhoras vão às lágrimas. A desolação e o silêncio permanecem por alguns minutos, até que uma salva de palmas corta o silêncio, todos começam a refazerse em meio aos comentários sobre como foi boa a encenação daquele ano.

Entre o fim da encenação e o reinício da procissão, passam alguns minutos, até que as autoridades religiosas e os leigos se reacomodem para o início do cortejo. Algumas pessoas têm lugares cativos, marcados tradicionalmente, sejam os que carregam o esquife, ou os senhores que tocam as matracas. Morosamente, a procissão vai tomando seu destino, as pessoas se colocam atrás do ataúde com a imagem de "Nosso Senhor Morto" coberta por um veludo roxo e alguns ramos de alecrim.

Como na encenação, o lugar ocupado na procissão demonstra a influência da pessoa na cidade: as famílias mais tradicionais dispõem-se logo atrás do andor que leva a imagem, enquanto a maioria dos recém-chegados e dos jovens se põem mais ao final do cortejo, muitos até preferindo não seguir toda a procissão, engajando-se apenas na metade do percurso. A procissão vai seguindo os "Passos" pelas principais vias do centro histórico, fazendo breves pausas, nos próprios "Passos", ou nas janelas, onde horas antes havia sido estendida uma toalha branca com uma vela ou a imagem de um santo ao centro.

Embora as mulheres fossem maioria, seja na procissão, ou no próprio credo católico, suas atuações nas procissões ficavam restritas aos papéis vistos como secundários pela comunidade, sendo o espaço central na organização da encenação ou na procissão deixado a cargo dos homens. Às mulheres cabem, geralmente, a decoração dos altares, a composição do cenário onde é encenada a peça, bem como puxar as rezas e litanias durante as procissões. 0 papel masculino, embora mais discreto, é o da organização central da peça, bem como o de carregar 0 andor dos santos e bater a matraca durante o préstito. 
Como já observei, a divisão dos papéis na festa não se restringe apenas à divisão de gênero: os lugares simbólicos das famílias tradicionais são guardados com bastante esmero; mesmo o trajeto da procissão é motivo de disputa entre os integrantes do grupo tradicional da cidade e da parcela do clero progressista. Durante uma das entrevistas, o senhor Ronaldo, membro do grupo tradicional, relatou-me uma querela sobre a eventual mudança do trajeto da procissão:

Olha! Eu não acho certo se mudar o trajeto da procissão da Semana Santa, pois nós, os moradores tradicionais de Mariana, já perdemos muito desde dos tempos de D. Oscar [Ex-Arcebispo]. Tirar a Semana Santa do Centro Histórico, é um absurdo, não podemos admitir isso, pois tradicionalmente foi realizada aqui e fazendo o percurso habitual, é muito mais bonito! Você vê, a rua Direita enfeitada, os Passos, é um lugar que tem tradição. Agora levar a procissão até lá na Colina, não tem graça nenhuma, fica meio esquisito, é longe e quebra a tradição. As festas, a Semana Santa, o Carnaval, são atrações que temos, não podem ser descaracterizadas. A saída do trajeto daqui do centro, será uma perda! Olha, tem muita gente, as pessoas mais velhas, o pessoal aqui do centro mesmo que não tá querendo mais participar das procissões, o trajeto é muito longo e cansativo. Agora vir dali, da "Prainha", das "Cabanas", as pessoas se reúnem aqui [no centro] participam da procissão e, voltam pra suas casas.

A referida contenda entre vigário da Sé e parcela da população tradicional que organiza as procissões foi decidida parcialmente a favor do clérigo, resultando na alteração de trajeto de parte das procissões - aquelas de menor importância aos olhos locais.

Com essas mudanças, bem como com a participação maior das "comunidades" nos festejos, o clero desejava abarcar uma parcela maior da população da cidade, reforçando os vínculos entre instituição religiosa e população recém-chegada. Esse intento poderia ser mais facilmente atingido alterando-se o trajeto das procissões, para que estas percorressem não só as ruas do centro histórico, mas também de alguns bairros da periferia "menos inóspita". No entanto, os moradores tradicionais continuaram ocupando predominantemente os papéis considerados mais nobres, tanto na organização das festas quanto nas procissões.

As alterações nas procissões, bem como a distribuição de alguns papéis menos importantes nas encenações da Semana Santa entre os moradores da periferia, é claro, trazia algum alento para a vontade participativa dos moradores do além-centro-histórico. No entanto, o novo trajeto abrigava apenas uma área intermediária entre o centro histórico e a periferia, muitas vezes habitadas por 
profissionais liberais ou mesmo por filhos dos moradores do centro histórico, os quais, pela carência de espaços para construção no antigo núcleo, mudavam-se para esses bairros, tão logo constituíam suas próprias famílias. Para as populações periféricas, que residiam nos bairros mais estigmatizados, a situação continuava bem parecida com a anterior, quanto o trajeto da procissão se restringia às ruas do núcleo-histórico.

Para Ademar, 57 anos, pedreiro, morador do bairro Santo Antônio, "Prainha", as comemorações da Semana Santa perderam muito da sua importância desde que mudou do distrito de Águas Claras para o Bairro:

Lá [Águas Claras], a gente tinha uma participação maió né? A gente participava da festa do Santo, da Semana Santa, das celebração, ajudando o padre, rezando novena. Eu lembro, que ia chegando essa época assim [Dezembro], as mulheres ia de casa em casa rezando a novena do natal, rezava na rua inteira. Então quando era na casa da gente, era uma festa, a gente chegava cansado da lida na roça, mas eu num ligava, a mulher já tinha feito uma broa pra receber as pessoas, sabe a gente ficava muito alegre... Na procissão, eu sempre levava 0 andor, eu o sinhô Joaquim Toneco, Jandim, tinha outros mas, nóis era tradicional. Sabe a gente participava... Era festa de Santa cruz, a gente enfeitava o cruzeiro chamava todo mundo, aí tinha uma comida, tinha uma sanfona, tinha até uma cachacinha, poca, né [risos]? Era festa de São Luiz de França, eu era o Mordomo do Mastro, enfeitava o mastro, todo mundo vinha(...) Agora fazê festa pro santo dos outros, é estranho né, a gente nem participa direito, não pode organizá, não pode bater a matraca, nem levar o santo... não tenho muita vontade de participar nessas festas não, eu fico aqui no meu cantinho (...)

Interpreto o argumento do migrante não como um esfacelamento de tradições populares constituídas em sociedades que se organizavam de forma tradicional. Embora tenha em mente esses processos de desencaixe, dos quais nos fala Giddens (1991), não acredito na organização das comunidades tradicionais como algo romântico em que as relações de poder e hierarquias se fazem ausentes, enquanto seus atores vivem em perfeita harmonia, intocados pela mão profanadora do progresso. Tampouco entendo a migração como uma violação, uma degradação da cultura popular, como enfatizam alguns autores:

A cultura e a tradição popular estão passando por um período crítico, motivado pela progressiva urbanização e pelo advento tecnológico no Brasil. Urge um trabalho sério de reflexão e conscientização se queremos evitar a perda generalizada dos valores culturais, artísticos e religiosos que nos foram legados por quase cinco séculos de história. (AZZI, 1978, p. 11). 
De perspectiva diversa, acredito que, mesmo considerando as comunidades "tradicionais" menos hierarquizadas e cortadas por menores disparidades, sejam de ordem social ou cultural - já que, se há um elemento unificador nos distritos rurais de Mariana, é a extrema necessidade a que estão submetidos seus habitantes - não consigo ver a ausência, mesmo nessas condições, de relações de poder e de "vontade de potência" por parte de seus atores. Da mesma forma, não tomo 0 processo de diversificação cultural, a que muitos chamam degradação, como algo necessariamente negativo; prefiro, ao contrário, as teorias que vêem esses processos enquanto negociação, criação e reelaboração culturais (SAHLINS, 1997; HANNERZ, 1997; CANCLINI 1998; AGIER, 2001).

Desta forma, esse argumento parece-me plausível se tomarmos o excerto da entrevista citado acima. Embora ressalte as funções sociais das festas, como a agregação de amigos e parentes, fica bastante claro, pelo menos aos meus olhos, a importância central que o entrevistado dá ao fato de participar da organização, de ser uma pessoa reconhecida e tradicionalmente importante para a organização daquela festa, o que, decerto, não o impediu de relatar e exaltar as funções sociais e até econômicas dos festejos.

Voltando à procissão, o cortejo atinge seu auge, como não poderia deixar de ser, ao enveredar pela Rua Direita. Nesta, os santos e uma boa parte dos fiéis recebe 0 tradicional banho de perfume. A comoção das senhoras mais idosas, que, das sacadas do casario, atiram o perfume, é impressionante. A chegada na Igreja da Sé sela o fim do cortejo; agora um a um, os fiéis vão adorar a imagem do corpo de "Nosso Senhor Morto". Neste momento, a hierarquia também se faz presente: entram primeiro os mais "nobres" e depois o restante da população.

Ainda que haja inúmeras disparidades de apropriação das cerimônias, uma coisa é inegável: a rememoração da paixão e morte de Cristo tem um lugar central na liturgia católica, contribuindo para reforçar os laços entre indivíduos e instituição.

\section{A DECOMPOSIÇÃO DA CENA: DIAS COMUNS}

Como pretendi deixar explicito em minha narrativa, o projeto identitário da cidade de Mariana tenta se manter incorrupto, em meio aos percalços de sua composição social. Aferrando-se à imagem de passado glorioso, em que a cidade teria gestado os sentimentos mais nobres que compõem a mineiridade, os "bons varões" marianenses tentam a todo o custo afastar a corrupção de suas memórias e de sua identidade. Mal comparando, vemos a cidade enquanto uma cena em que 
o diretor nem sempre tem o domínio da situação, precisando barganhar com seus atores, nesta ou naquela interpretação, embora os mesmos nem sempre saibam disso. Os contra-regras tentam a todo custo evitar a visão das cordas que amarram toscamente o cenário, os remendos das cortinas, bem como todo o improviso que constitui a cena. A tarefa do diretor é fazer os atores representarem o melhor possível, para que as pessoas fixem neles sua atenção e não vejam a precariedade e superficialidade do cenário, que se desfaz diante do espetáculo.

A cidade, enquanto cena, mostra-nos lugares dedicados à memória do catolicismo. A Mariana que se revela não é a da periferia com suas cartomantes, seus templos pentecostais, ou seu terreiro de umbanda hermeticamente guardado e só pronunciado em cochichos ao "pé-da-orelha". A faustosa cidade é a das igrejas barrocas, a cidade-dos-bispos, de Cláudio Manoel, de Frei Durão, de Athayde, Gomes Freire e Alphonsus de Guimarães, que formam uma armadura lustrosa, que pretende refletir a cidade e, ao mesmo tempo, impedir a visão de suas partes.

No entanto, ainda que obliteradas da "cena oficial" citadina, as várias cenas destoantes da identidade marianense teimam em aparecer e comparecer ao centro do palco. Nos dias comuns, tomam o espaço da cidade e, mesmo a contra gosto dos que ali habitam, fazem a cotidianidade das ruas e compõem, junto com as igrejas e o casario, o cenário da cidade.

Num dia comum, atravessando a Rua Direita, vejo duas senhoras, cabelos em forma de coque, saias longas, levando com orgulho debaixo do braço a bíblia, objeto que as diferencia das demais. Mais à frente, senhoras esmolam sentadas nas esquinas, em que, talvez um dia, os mais nobres senhores das Minas tenham colocado seus pés. No adro da Igreja da Sé, vagabundos e bêbados esperam ávidos algum turista, que, em troca de uma fábula, lhes oferecem trocados. Até o final da tarde, muitos vão e vêm pelas ruas e becos da cidade, com objetivos díspares, mas sempre guardados por torres e cruzes, que têm pouco significado senão 0 de oferecer um abrigo da chuva ou do sol, ou até suscitar um mecânico sinal da cruz, quando cruzadas de frente. Para esses que agora cortam o espaço central da cidade, Alphonsus e Athayde não fazem mais eco aos seus ouvidos que João ou José. Olhando as igrejas de São Francisco e do Carmo, o que lhes aguça mais a curiosidade é antes a proximidade dos templos do que os contornos e as formas — “só não entendo o porquê de se construir duas igrejas tão perto, será que tinha tanta gente assim aqui em Mariana antigamente?" ${ }^{12}$.

\footnotetext{
${ }^{12}$ Pergunta de um rapaz que atravessava a Praça Minas Gerais, quando um Guia Turístico explicava as efemérides do conjunto arquitetônico da praça, que conta ainda com a Casa da Câmara e Cadeia.
} 


\section{CONSIDERAÇõES FINAIS}

As desigualdades sociais analisadas neste artigo não são uma característica que torna a cidade de Mariana sui generis entre os agrupamentos humanos; ao contrário, como bem observa Norbert Elias em seu posfácio à edição alemã de Estabelecidos e outsiders, "as desigualdades entre os indivíduos estão entre as marcas distintivas e recorrentes das sociedades humanas" (2000, p. 199). Tais hierarquizações sociais e estigmas não advêm da fraqueza de caráter de um lado ou de outro dos grupos envolvidos, mas das narrativas que contamos a nós mesmo sobre quem somos: são, para lembrar mais uma vez Elias (2000), características estruturais da sociedade. Isto não quer dizer que devamos nos contentar com elas; pelo contrário, se há um papel que ainda cabe às Ciências Sociais depois de Nietzsche e Foucault é o de denunciar tais mazelas da espécie humana.

Neste artigo em especial procuro demonstrar que, mesmo compreendendo a desigualdade como um traço estrutural e mais ou menos perene ao longo da história humana, existem momentos em que tais processos se tornam mais agudos, como nas crises econômicas e convulsões sociais. No caso de Mariana, isso aconteceu após um intenso e desordenado processo de urbanização, que revolveu não apenas seu espaço físico, mas deu uma nova configuração ao espaço sócio-simbólico da cidade. Nesse ínterim, a antiga população se viu acossada pelo medo do novo, pela incerteza. Esse sentimento foi direcionado aos que não se encaixavam no mapa cognitivo local, que tornaram turvo o que devia ser transparente, obscureceram fronteiras que deviam ser vistas claramente. Assim, foi necessário traçar novas fronteiras e, a seguir, preenchê-las de sentido.

Por fim, elegi a religião, em especial o evento da Procissão da SextaFeira Santa, como metáfora privilegiada para por à luz as relações de disputa, desigualdade e poder entre os dois grupos inscritos nesse processo. 0 fenômeno religioso se mostra como um lugar privilegiado para o cientista social, pois constitui o que Mauss (1974) chamou de fato social total, uma vez que condensa em sua totalidade a sociedade e suas instituições. Dito de outra forma, expõe processos que, na maioria das vezes, aparecem mitigados no dia-a-dia, escondidos na rotina do cotidiano.

Neste estudo, privilegiei conscientemente as funções nomizadoras (BERGER, 1985) do fenômeno religioso, porém, isso não vale dizer que a religião não possa ser vista sob outro prisma, por exemplo, como fomentadora de revoluções, racionalismos ou catalisadora dos mais diversos obscurantismos da face humana. 


\section{REFERÊNCIAS}

AGIER, Michel. Distúrbios identitários em tempos de globalização. Mana, Rio de Janeiro, vol.7, n. 2, 2001, p.7-33.

ALEXANDER, Jefrey. 0 novo movimento teórico. Revista Brasileira de Ciências Sociais, São Paulo, vol. 2, n. 4, jun, 1987, p. 5-28,

ALMEIDA, Carla Maria C. Minas Gerais de 1750 a 1850: bases da economia e tentativa de periodização. Revista de História, Mariana, n. 5, 1995, p. 88-111.

AZZI, Riolando. Catolicismo popular no Brasil. Petrópolis: Vozes, 1978.

BAUMAN, Z. 0 mal-estar da pós-modernidade. Rio de Janeiro: Jorge Zahar, 1998. Globalização: as conseqüências humanas. Rio de Janeiro: Paz e Terra, 1999.

Comunidade - A busca por segurança no mundo atual. Rio de Janeiro: Paz e Terra, 2003.

BELLAH, Robert. The Broken Covenant: American civil religion in time of trial. Chicago: The University of Chicago Press, 1984.

BERGER. Peter. O Dossel Sagrado: elementos para uma teoria sociológica da religião. São Paulo: Paulinas, 1985.

BOURDIEU, Pierre. O poder simbólico. Lisboa: Difel, 1989.

. Efeitos de lugar. In: BOURDIEU, Pierre (org.). Miséria do mundo. Petrópolis: Vozes, 1998, p.159-166.

BOVO, Luís Sartorelli. Mariana: berço de varões ilustres. Coleção Evocando fatos e homens, São Paulo, vol. 2, (SE), 1976

BURTON, Richard Francis. Viagem do Rio de Janeiro a Morro Velho. Belo Horizonte: Itatiaia; São Paulo: Edusp, (Reconquista do Brasil, 36), 1975.

BRUCE, Steve. The supply-side model of religion: the Nordic and Baltic States. Journal for the scientific study of religion, Provo, vol. 39, 2000, p. 32-46. . Les limites du "marché religieux". Social Compass, Louvain-La-Neuve, vol. 53, n. 1, 2006, p. 33-58. Disponível em: <http://scp.sagepub.com/cgi/content/ abstract/53/1/33> Acesso em 26 de junho de 2008. 
CAMÊLLO, Roque J. 0. (org). 16 de Julho: o dia de Minas. Discursos, pronunciamentos, ensaios, crônicas e poemas sobre a data constitucional mineira. Belo Horizonte: Editora Lemi, 1991

CANCLINI, Nestor Garcia. Culturas híbridas poderes oblíquos: estratégias para se entrar e sair da modernidade. São Paulo: EDUSP, 1998.

. Consumidores e cidadãos: conflitos multiculturais da globalização. Rio de Janeiro: Ed UFRJ, 2001. . A globalização imaginada. São Paulo: Iluminuras, 2003.

CIPRIANI, Roberto. De la religion diffuse à la religion des valeurs. Social Compass, Louvain-La-Neuve, vol. 40, n. 1, 1993, p. 91-100. <http://host.uniroma3.it/ docenti/cipriani/saggi.htm> Acesso em 10 de Janeiro de 2008.

DURKHEIM, Emile. As formas elementares da vida religiosa. São Paulo: Martins Fontes. 2003.

DAMATTA, Roberto. A casa e a rua: espaço, cidadania, mulher e morte no Brasil. São Paulo: Brasiliense, 1985.

ELIAS, Norbert e SCOTSON, John L. Os estabelecidos e outsiders: sociologia das relações de poder a partir de uma pequena comunidade. Rio de Janeiro: Jorge Zahar Editor, 2000.

FISCHER, Mônica. Mariana: os dilemas da preservação histórica num contexto social adverso. Dissertação, Mestrado em Sociologia, Departamento de Ciências Sociais, Universidade Federal de Minas Gerais, Belo Horizonte, 1993.

FONSECA, Cláudia Damasceno. Mariana: gênese e transformação de uma paisagem cultural. Dissertação de Mestrado, Geografia Urbana, Instituto de Geociências, Universidade Federal de Minas Gerais, Belo Horizonte, 1995.

FUNDAÇÃO JOÃO PINHEIRO. Relatório para a preservação dos centros históricos de Ouro Preto e Mariana, 1978.

GIDDENS, Antony. As conseqüências da modernidade. São Paulo: Unesp, 1991.

GRACINO JÚNIOR, Paulo. Visões da cidade: memória, poder e preservação em Mariana. Revista Vivência, Natal, vol. 28, 2005, p. 179-199.

HALBWACHS, Maurice. A memória coletiva. São Paulo: Vértice, 1990. . Les cadres sociaux de la mémoire. Paris: Albin Michel, 1994. 
HALL, Stuart. Quem Precisa da Identidade? In: SILVA, Tomaz Tadeu (org.). Identidade e diferença. Perspectiva dos estudos culturais. Petrópolis: Vozes, 2000. . A identidade cultural na pós-modernidade. Rio de Janeiro: PD \&A Editora, 2001.

HANNERZ, Ulf. Fluxos, fronteiras e híbridos: palavras-chave para a Antropologia transnacional. Mana, Rio de Janeiro,, vol. 3, n. 1. Rio de Janeiro, 1997, p. 07-39. HERVIEU-LÉGER, Danièle. La religion pour mémoire. Paris: Cerf, 1993.

. Representam os surtos emocionais contemporâneos o fim da secularização ou o religião? Religião \& Sociedade, Rio de Janeiro, vol. 18, n. 1, 1997, p. 31-48. $2005 \mathrm{a}$. o peregrino e o convertido : a religião em movimento. Lisboa: Gradiva, Catolicismo: a configuração da memória. Rever, São Paulo, n. 2, 2005b. Diponível em: <http://www.pucsp.br/rever/rv2_2005/t_leger.htm > Acesso em 24 de junho de 2008.

HERVIEU-LÉGER, Danièle \& WILLAIME, Jean-Paul. Sociologies et religion: approches classiques. Paris: PUF, 2001.

INSTITUTO BRASILEIRO DE GEOGRAFIA E ESTATÍSTICA (IBGE). Censo de 1970. . Censo de 1980.

. Censo de 1990.

. Censo de 2000.

JEUDY, Henri-Pierre. Memórias do social. São Paulo: Forense, 1995.

LEFEBVRE, Henry. O direito à cidade. São Paulo: Editora Moraes, 1991.

LYOTARD, Jean-François. A condição pós-moderna. Lisboa: Gradiva, 1989.

LUKES, STEVE. Émile Durkheim. Madrid: Editora C.I.S, 1984.

MARTELLI, Stefano. A religião na sociedade pós-moderna: entre a secularização e a dessecularização. São Paulo: Paulinas, 1995

MAUSS, Marcel. Ensaios sobre a dádiva. Forma e Razão das trocas nas sociedades arcaicas. In: Sociologia e Antropologia. São Paulo: EPU, 1974.

NÚCLEO DE ESTUDOS APLICADOS E SÓCIO-POLÍTICOS COMPARADOS (NEASPOC-UFOP). Assessoria Popular de Mariana, 2000. 
NORA, Pierre. Entre memória e história: a problemática dos lugares. História e Cultura. Projeto História, São Paulo, n. 10, 1993, p. 7-28.

OR0, Ari Pedro \& STEIL, Carlos A. (orgs.), Globalização e religião. Petrópolis: Vozes, 1997.

PACE, Enzo. Salvation Goods, the Gift Economy and Charismatic Concern. Social Compass, Louvain-La-Neuve, vol., 53, n. 1 2006, p. 49-64. Disponível em: < http:// scp.sagepub.com/cgi/content/abstract/53/1/49> Acesso em 4 de junho de 2008.

PARSONS, Talcott. O sistema das sociedades modernas. São Paulo: Pioneira, 1974.

PEIXOTO, Paulo. "Porto Feliz": patrimônio em segurança. Horizontes Antropológicos. Porto Alegre, vol. 11, n.23, 2005, p. 145-161.

POLLAK, Michael. Memória, esquecimento, silêncio. Estudos Históricos, Rio de Janeiro, n. 3, CPDOC, 1989, p. 3-13.

SAHLINS, Marshall. 0 pessimismo sentimental e a experiência etnográfica: por que a cultura não é um objeto em extinção (Parte I). Mana, Rio de Janeiro, vol. 3, n. 1, 1997, p. 41-73.

VILAÇA, Helena. Imigração, etnicidade e religião: o papel das comunidades religiosas na integração dos imigrantes da Europa do Leste. Lisboa: ACIDI, 2008. 